\title{
New coronavirus: what does nursing have to learn and teach in times of a pandemic?
}

Novo coronavírus: o que a enfermagem tem a aprender e ensinar em tempos de pandemia? Nuevo coronavirus: ¿Qué tiene la enfermería para aprender y experimentar en tiempos de pandemia?

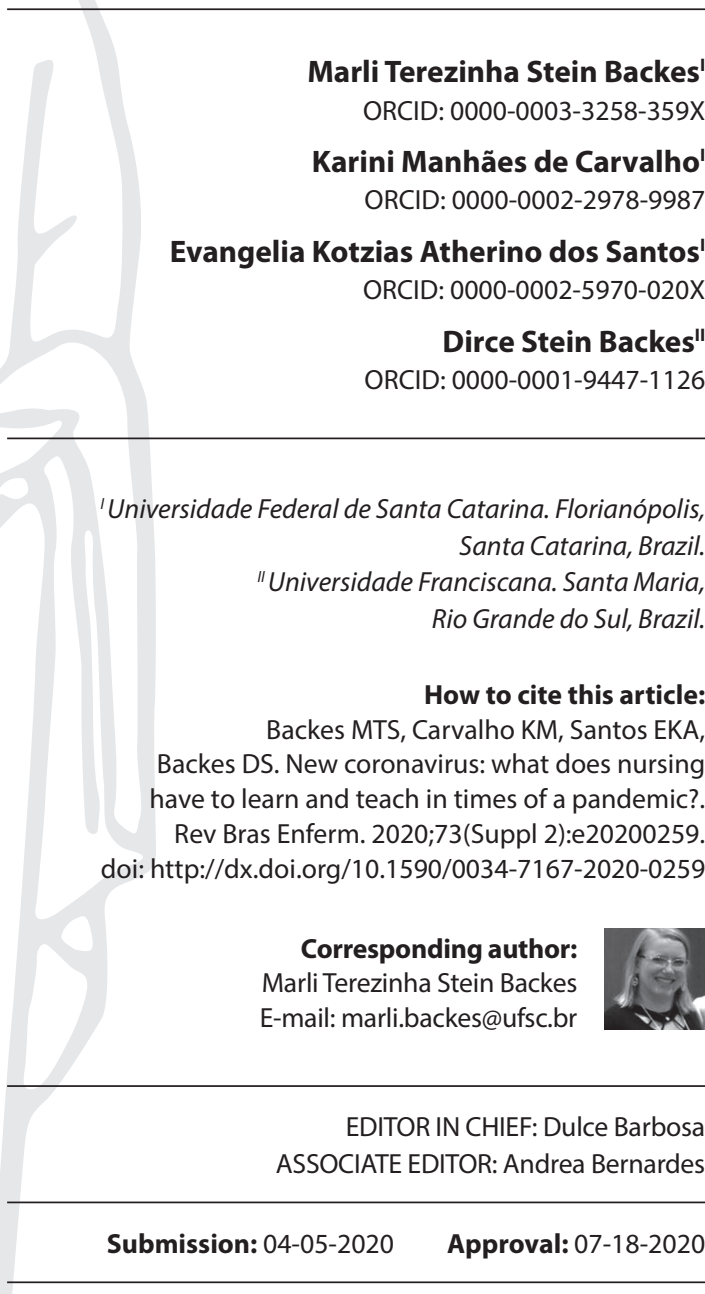

\begin{abstract}
Objective: To promote a theoretical reflective analysis of what nursing has to learn and teach to global society in times of OVID-19 pandemic. Methods: Reflective theoretical essay aimed at contributing new knowledge and raising new questions, based on the assumptions of Edgar Morin's complexity thinking, subsidized by readings of texts extracted from electronic databases, as well as speeches by health professionals available in open communication tools. Results: COVID-19 reiterates that the biological warfare of the current pandemic is not fought with nuclear or fire weapons, but with care in its multiple dimensions: physical, emotional, spiritual, family, social, political and economic. Final considerations: Nursing has to learn and teach global society that its main object of work, care, is related to the expansion of systemic interactions and associations and the capacity to strengthen the interlocution with complex reality.
\end{abstract}

Descriptors: Nursing; Nursing Care; Nurse's Role; Coronavirus; Pandemics.

\section{RESUMO}

Objetivo: Promover uma análise teórico-reflexiva sobre o que a enfermagem tem a aprender e ensinar à sociedade global em tempos de pandemia da COVID-19. Métodos: Ensaio teóricoreflexivo que visa contribuir com novos conhecimentos e suscitar novos questionamentos, com base nos pressupostos do pensamento da complexidade de Edgar Morin, subsidiado por leituras de textos extraídos de bases de dados eletrônicas, bem como de discursos de profissionais de saúde disponíveis em ferramentas de comunicação aberta. Resultados: A COVID-19 reitera que a querra biológica da pandemia em curso não se combate com armas nucleares ou de fogo, mas com o cuidado em suas múltiplas dimensões: física, emocional espiritual, familiar, social, política e econômica. Considerações finais: A enfermagem tem a aprender e ensinar à sociedade global que seu principal objeto de trabalho, o cuidado, está relacionado à ampliação das interações e associações sistêmicas e à capacidade de fortalecer a interlocução com a realidade complexa.

Descritores: Enfermagem; Cuidados de Enfermagem; Papel do Profissional de Enfermagem; Coronavirus; Pandemias.

\section{RESUMEN}

Objetivo: Promover un análisis teórico-reflexivo sobre lo que la enfermería tiene que aprender y enseñar a la sociedad global en tiempos de la pandemia/COVID-19. Métodos: Ensayo teórico-reflexivo que apurta nuevos conocimientos y plantear nuevas interrogantes, basado em supuestos del pensamiento de complejidad de Edgar Morin, subvencionado por la lectura de textos extraídos de bases de datos electrónicas, así como discursos de profesionales de la salud disponibles en herramientas de comunicación abierta. Resultados: El COVID-19 reitera que la guerra biológica en curso de la pandemia no se libra con armas nucleares o de fuego, sino con cuidado en sus múltiples dimensiones: física, emocional, espiritual, familiar, social, política y económica. Consideraciones finales: La enfermería tiene que aprender y enseñar a la sociedad global que su principal objeto de trabajo, el cuidado, está relacionado con expansión de las interacciones y asociaciones sistémicas y capacidad de fortalecer el diálogo con la realidad compleja.

Descriptores: Enfermería; Cuidado de Enfermería; Papel del Profesional de Enfermería; Coronavirus; Pandemias. 


\section{INTRODUCTION}

The disease caused by the new coronavirus (severe acute respiratory syndrome coronavirus 2, SARS-CoV-2), enveloped RNA viruses, commonly found in humans, appeared in the city of Wuhan in December 2019 and spread in a few days throughout China, demonstrating a broad spectrum of severity and lethality, including in patients with no apparent symptoms. These and other factors have contributed to its rapid spread around the world and its configuration as a pandemic ${ }^{(1-2)}$.

The impact of the chaos that this pandemic has presented can be demonstrated representatively by the number of people infected and the number of deaths already recorded. Considering the official records so far (03/07/2020), 10,710,005 cases and 517,877 deaths have occurred in the world; the country with the highest number of cases is the United States $(2,671,220$ cases and 127,858 deaths) and, in second place, is Brazil, considered the current epicenter of the pandemic, with a total of $1,448,753$ cases and 60,632 deaths ${ }^{(3)}$. However, these numbers are possibly even higher if we consider the low number of tests performed and the sub-notifications.

The new coronavirus COVID-19 is an infectious disease caused by a new virus, never before identified in humans. It causes a flu-like respiratory illness and has symptoms such as dry cough, fever, dyspnea, myalgia or fatigue and, in more severe cases, pneumonia; in addition, it has high transmissibility. One infected person spreads the disease to two or three others on average, which represents an exponential rate of increase in a few days. COVID 19 represents, under this approach, a threat to the world's public health and to human life, since it can victimize elderly people with previous health problems, as well as cause the death of healthy adults; and, as if this were not enough, there is still no drug therapy or proven vaccines for the prevention and specific treatment of the disease ${ }^{(4-5)}$. In addition, non-pharmacological measures such as physical/social isolation and care such as hand hygiene are prophylactic measures to mitigate the transmissibility of the disease.

Therefore, we find ourselves facing chaos, which is defined by Edgar Morin, one of the most important thinkers of today, as an irreversible or unstable phenomenon, not reducible to a mathematical reality. It means that, as the world globalizes and becomes more complex and chaotic, human minds expand more and more to accompany this development, which in turn enables the emergence of even more chaotic phenomena. In the author's view, it is necessary to overcome a thought that reduces and fragments by another thought that distinguishes, unites and integrates, that is, by a complex, dynamic and evolutionary thought that does not paralyze. The author acknowledges that there are no problems that are not complex and, consequently, there is no place for simplified knowledge in this world ${ }^{(6)}$.

Faced with this uncertain, vulnerable and chaotic scenario, health professionals have been working intensively and exemplarily on the front line. Here, nursing professionals stand out in particular, who are the protagonists in the organization and management of care, as well as in the fight and control of the propagation of COVID-19. They act daily in direct patient care, putting their own health at risk, often with work overload and often in precarious conditions. Moreover, they still need to face the fear and frustration of having to witness people dying in their thousands due to lack of ventilator support, and they need to support choices about who should or should not continue living ${ }^{(7)}$.

How to deal with such global and, at the same time, local and existential complexity? What lessons can be learned and taught in this chaotic scenario? What does nursing have to learn and teach to global society in times of pandemic? What even distinguishes it in being and doing professional in Brazil and the world?

\section{OBJECTIVE}

To promote a theoretical reflective analysis of what nursing has to learn and teach to global society in times of pandemic caused by the coronavirus/COVID-19, from the perspective of complexity thinking.

\section{THEORETICAL REFERENCE OF THE COMPLEXITY AND MOTIVATIONS FOR THE CONSTRUCTION OF THIS STUDY}

This is a theoretical-reflexive essay which aims to contribute new knowledge about COVID-19 and, above all, to raise new questions based on the assumptions of Edgar Morin's thought of complexity, subsidized by readings of texts extracted from electronic databases. Morin's thinking has influenced the most diverse fields of knowledge and has been employed as a theoretical reference in nursing research. From the criticism of classical science, characterized by the determinism and linearity of the phenomena, it points out new paths and possibilities to humanity, especially in times of uncertainty and chaos.

Integrative review carried out in 2014 highlighted a growth in scientific production related to complex thinking in nursing and health management ${ }^{(8)}$. According to the authors, complex thinking is employed in two ways, mainly: as a theoretical reference for care management discussions; and as a management model for living and unpredictable nursing and health organizations, since it encompasses completeness, attention to support networks, multi-disciplinarity and the articulation of knowledge to promote the organization of complex adaptive systems in organizations in a deeper and more contextualized manner.

This essay seeks to portray connections between a traditional view of science and an understanding of the complexity of reality - the ongoing pandemic does not detract from clarity, order and determinism, but considers these to be insufficient for the understanding of multidimensional nursing care. Complexity is at the core of the relationship between the simple and the complex, given its simultaneously antagonistic and complementary character. Complex thinking incorporates uncertainty and is able to conceive the organization, to contextualize and globalize, but at the same time it can recognize what is singular and concrete ${ }^{(6,9)}$.

This article is based on reports from nursing professionals on the national scene, drawn from various media. Given the characteristic of the work and the fact that the speeches used were made available in open media, it was not necessary for the Research Ethics Committee to assess this study. However, the anonymity of the names of the subjects was maintained.

The varied expressions of nursing professionals mobilize reflection, inquiry and the desire to contribute in some way to the 
advancement of science, especially in times of pandemic. To exemplify these instigations, the following are statements by nurses (P1, P2, P3, P4) randomly selected, which will serve as a source of inspiration for the theoretical-reflexive discussion on the differential of nursing care/care from the perspective of complexity thinking.

Overload of work, lack of personal protective equipment, reduced number of professionals, stress, deaths, uncertainties and the fear of what may still come... a daily chaos. But, we're Nursing, we're the care professionals. This virus reminds us that my existence is intertwined with the existence of the other and that at this moment there are no professional boundaries, but care professionals. (P1)

The complication of this virus is pneumonia. It sticks to the lung. It's like a plastic bag that sticks... the respiratory crisis develops in two or four hours. Although in a lighter form, I'm doing this experiment in practice. I saw it, it died on my hands! People who were fine, people in their 60s. It's all still here, chaos. It's chaos for the whole world. Here there are no more hospital beds and they're sending patients to other countries. (P2)

When you watch it on TV, when you read the news on the internet, it's not the same thing... I see that these patients don't get better. Of all the patients we've intubated, we haven't been able to get anyone out of the intubation yet. That's hard because you don't see the patient evolving in a positive way... A very sad situation happened that really moved me. He was conscious, and we had to warn him that he was going to be intubated, and he made a video call with his family. So we were in the room while he was saying goodbye to this family. He said goodbye to his son, to his wife, he cried, he was very moved... I don't think anyone was ready for that. And I'm more worried because I think it's going to get a lot worse before it gets any better. (P3)

We're all scared. We are all afraid of the disease, of the lack of access to treatment for all, of the lack of respirators, of having to choose between those who should continue living. We are afraid of the loss of loved ones... that fear will increase our empathy and leave us less judges and more careful. May fear help us understand the true sense of care. (P4)

\section{NURSING IN BRAZIL AND THE WORLD: WHAT SETS IT APART?}

The 2020 Nursing Now Campaign and the OVID-19 pandemic: What this apparently antagonistic combination of phenomena has to say to the world and to nursing itself? Nursing professionals are recognized worldwide as the professionals of care, the professionals of the front line in any situation; especially in times of pandemic, they are usually the first to have contact with the patients who present characteristic signs and symptoms.

The world health agencies and combat actions reiterate, in a remarkable way, that this biological war of the pandemic is not fought with nuclear or fire weapons, but by the care in its multiple dimensions: physical, emotional, spiritual, family, social, political and economic. In other words, the answer is through integral and integrative care, since these dimensions are complementary and therefore need to be understood in their interrelationships.

In the statement "We are afraid... that fear will help us to understand the true meaning of care", it became evident that the nursing professional is also a human being like any other. It is a professional who feels fear, vibrates with the improvement of the patient, dreams of better health conditions, but in this time of pandemic, often anguishes and fears the uncertainties of the future. If, on the one hand, the testimonies carry a feeling of powerlessness and frustration, expressing the vulnerability of the nursing professional in the face of adversities to which there are no answers, on the other hand, they highlight the traditional and deterministic view of caring as a reflection of Cartesian knowledge that needs to find favorable answers to all situations and promote healing at any price, considering that society is not prepared to "lose"(9-10).

It is recognized that classical science has dissolved the complexity of phenomena to reveal the hidden simplicity of the laws of nature. This behavior was justified by the fact that the best hypothesis was the simplest or the one that appealed to a smaller number of explanatory entities ${ }^{(6)}$. Today, however, it is shown that science needs not only a knowledge capable of considering the complexity of reality, but also of transforming this knowledge of complexity into systemic thinking, as described by two deponents: "This virus reminds us that my existence is intertwined with the existence of the other and that at the moment there are no professional boundaries, but professional care..."; "... that fear increases our empathy and leaves us less judges and more careful".

However, what do we really mean by nursing care? What even distinguishes nursing care from any other care? Based on an extended and systemic analysis, nursing care can/must be defined as a complex phenomenon, systematized through multiple relationships, interactions and associations, with a view to promoting and recovering the health of the human being in its integral form and articulated with all that surrounds it ${ }^{(11)}$.

In periods of physical/social isolation, society feels and suffers the consequences of these measures, which have an impact on the physical, social and mental health of people. It is more strongly understood the real meaning of the (lack of) care, that is, there are people who avoid going to hospitals when they get sick for fear of contracting COVID-19 and end up dying at home due to a heart attack; the care of children in the school phase at home; the preventive actions in the care of the elderly and other groups at risk for COVID-19; the care with the fundamental social labels; and others. In this direction, the care with the frequent hygienization of the hands, the correct use of the individual protection equipment, both at the moment of paramentation and in the deworming, which are essential cares for the nursing professionals, but repeatedly are relegated to a second plan, should be highlighted. There is then talk of care, but not just any care.

The emphasis is on professional nursing care, which, although dynamic and systemic, repeatedly fails to find answers to the modification of the course of events and domains of life, because living is unpredictable and the whole notion of balance in movement is in the logic of life $\mathrm{e}^{(9)}$.

It is recognized that the nursing professional commonly has the need to find and give answers to different questions or situations of daily life, an attitude also expected by society, which hardly feels provoked to new questions. When the nursing professional does not find the answers in him/herself or the other, he/she sometimes gets frustrated, isolates, depresses and sees himself/ 
herself as incompetent for the function, since he/she considers him/herself "trained to save lives". Such reactions become evident as professionals perceive that patients do not evolve through the treatment instituted, according to the express: "Of all those patients we intubated, we haven't been able to get anyone out of the intubation yet. This is difficult because you don't see the patient evolving in a positive way...".

Social reality is in constant evolution, but not necessarily in its human dimension. Connections with the distant are easily promoted, but difficulties are encountered in promoting healthy connections with those closest to them. So, the following questions arise: What do they distinguish and differentiate between nursing care and any other non-professional care? What skills and abilities are needed to promote nursing care in times of uncertainty and chaos? What attitudes need to be developed in order to maintain dynamic integration and not "sink" between the possible currents of the crossing? How does one save lives and promote health in times of pandemic, when there is still no effective treatment ("right answer") and not even clarity and security for tomorrow? Finally, why do we need absolute certainties or ready-made recipes, knowing that creativity emerges from interactive possibilities and seemingly adverse and contradictory situations?

\section{FEAR AND CHAOS: WHAT DO THEY TEACH US?}

The human ability to imagine the worst has no limits. We know that the subject of natural disaster is not new. It is, in fact, as old as fear. The pandemic is not treated as an invention, but as something that happens at long intervals of time. In the same way, the catastrophe, experienced in all times, is revealed either by the action of fire or by the action of water. These phenomena allow the Earth and humanity to (re)organize and learn that in chaos the best possibilities for transformation can arise. The order is intertwined with disorder and chaos at the same time ${ }^{(6)}$. However, how does one visualize a new order amidst the uncertainties, disorders and chaos caused by COVID-19?

The expression "we are all afraid" and so many other manifestations mobilize a series of inquiries that are not limited to nursing professionals. What or what fear are you talking about? Fear of contracting the disease? Fear of dying? Fear of losing a loved one? Fear of not having access to a mechanical fan? Fear of having to decide, in the face of the lack of equipment such as the mechanical ventilator, who has priority; whether the youngest or the oldest? Fear of having to choose between who will continue to live and who will end up dying in view of the scarcity of resources, such as lack of beds, respirator and intensive care unit? Fear of loneliness? Fear of unemployment? Fear of income reduction? Fear of the collapse of the health system and the economy? Fear of being short on food and having nowhere to buy it? Fear, simply fear, but of what and who?

Fear is an emotional constitutive of the human being, that is, it is an essentially subjective emotion. Even if it involves the collective, it starts from the assumption that it is an individual or, more appropriately, intersubjective feeling. It is, therefore, a recurring, everyday emotion and implies the perception of everything that surrounds us, being apprehended in concrete phenomena. Fear, in its affirmative character, mobilizes new ways of being and acting and moves the human being in search of himself and the other. Thus, such emotion is established in interaction, being a product of the relationship between individuals, culture and society ${ }^{(12)}$.

The human being does not weave the web of life, but is one of the threads that make up the complex unit. Whatever they do to that web, they do to themselves ${ }^{(9)}$. Therefore, the human being is continuously and fully connected to the events that originate from unexpected events, such as the COVID-19 pandemic. And these, in turn, unfold generating emotions of greater or lesser density. Among them, the emotion associated with fear is one of the most recurrent, as evidenced in the testimonies "we are all afraid".

The thought of complexity aims, among other objectives, to question the opposition between facts and nature, in addition to reflection on the meaning, values and truths concerning science. For the author, science itself has long forged simplifying homogeneities. The objects were often separated from their context and the context of the observers, so that the disciplines were fragmented and made dialogue between the sciences impossible. These reductions unified, quantified and disregarded what was multiple and, while acknowledging that this was responsible for advances in knowledge (e.g. about the atom and the molecule), one must also admit the disregard of chance and contingency, as in real time regarding the ongoing pandemic $\mathrm{c}^{(6,9)}$.

The thought of complexity, on the other hand, induces the expansion of knowledge, connection, interconnection and understanding of the part in the whole, as well as the whole in each part and, in this way, finding new paths in the midst of uncertainty, complex and chaos $^{(9)}$. The speech "We're afraid of loss... that fear will increase our empathy and leave us fewer judges and more careful. May fear help us understand the true sense of care" indicates that during disorder and chaos, new opportunities always emerge. Conceiving chaos from this perspective does not mean molding the crisis into the lamenting of lost opportunities, but rather potentializing them in the freedom of imagination and alternatives.

To perceive and welcome reactions of fear, inherent or resulting from risk situations, and to understand them in the context to which their agent was exposed, is to ensure a better adaptation to the new reality and to enable a more resilient society and more aware of its responsibility in building a new social organization ${ }^{(9)}$.

It is precisely when great phenomena arise, such as pandemics that shake certain populations and when everything seems to be lost that the incredible capacity of people to reorganize them and face the vicissitudes results in real life lessons. Thus, what lessons nursing has to learn and teach to global society in times of pandemic caused by the new coronavirus/COVID-19? What needs to be reorganized in the nursing performance? How can we prevent illness and death of the nursing professionals themselves? What to celebrate in the 2020 Nursing Now Campaign in honor of Nursing Professionals?

Health organizations have mobilized with actions to contain the OVID-19 pandemic. In the same way, nursing and health professionals have acted in the front line, in an exemplary way, in the fight of COVID-19; and, even in the face of the difficulties and precarious working conditions, they have looked after and cared for with dignity of health and human life. In view of this 
scenario, the present work brings significant contributions and reflections based on Edgard Morin's reference on the nursing performance in face of this pandemic.

\section{FINAL CONSIDERATIONS}

Theoretical reflective analysis of what nursing has to learn and teach to global society in times of pandemic caused by the new coronavirus/COVID-19, from the perspective of complexity thinking, did not seek to give ready answers, but attempted to (re)think the thought through new questions, perhaps a little more complex.

Nursing has much to learn and teach with and in global society that its main object of work, care, is related to the expansion of systemic interactions and associations and the ability to strengthen the interlocution with complex reality, especially in times of pandemic in which the new coronavirus/COVID-19 is the villain. It is necessary, gradually, to overcome the paradigm of simplification and consider complexity as inducing new possibilities and opportunities to (re)organize nursing as a science and profession highlighted at the moment.

The thought of complexity, illuminating multidimensional nursing care, transcends the sovereignty of the instituted order and conceives the dialogical relation between order, disorder and organization. Under this approach, the nursing professional assumes, besides being the protagonist, a mediating and interlocutor role in care, which implies considering human singularities and multidimensionality. To achieve this interactive and associative process, it is necessary to transcend the paradigm of simplification, characterized by principles of disjunction, reduction and fragmentation, and gradually consider the complexity of being and nursing.

\section{FUNDING}

We thank CAPES for promoting the postgraduate program.

\section{REFERENCES}

1. Li R, Pei S, Chen B, Song Y, Zhang T, Yang W, et al. Substantial undocumented infection facilitates the rapid dissemination of novel coronavirus (SARS-CoV2). Science. 2020;368(6490):489-93. doi: 10.1126/science.abb3221

2. Stoecklin SB, Rolland P, Silue Y, Mailles A, Campese C, Simondon A, et al. First cases of coronavirus disease 2019 (COVID-19) in France: surveillance, investigations and control measures, January 2020. Euro Surveill. 2020;25(6):pii=2000094. doi: 10.2807/1560-7917. ES.2020.25.6.2000094

3. World Health Organization (WHO). Coronavirus disease 2019 (COVID-19) Situation Report - 165. Data as received by WHO from national authorities by 10:00 CEST, 3 July 2020 [Internet]. 2020[cited 2020 Apr 10]. Available from: https://www.who.int/docs/default-source/ coronaviruse/situation-reports/20200703-covid-19-sitrep-165.pdf?sfvrsn=b27a772e_2

4. Cui J, Li F, Shi ZL. Origin and evolution of pathogenic coronaviruses. Nat Rev Microbiol. 2019;17(3):181-92. doi: 10.1038/s41579-018-0118-9

5. Belasco AGS, Fonseca CD. Coronavirus 2020. Rev Bras Enferm. 2020;73(2):e2020n2. doi: 10.1590/0034-7167-2020730201

6. Morin E. A cabeça bem-feita: repensar a reforma, reformar o pensamento. Rio de Janeiro: Bertrand Brasil; 2014.

7. Rosenbaum L. Facing Covid-19 in Italy - ethics, logistics, and therapeutics on the epidemic's front line. N Engl J Med. 2020;382:1873-5. doi: 10.1056/NEJMp2005492

8. Copelli FHS, Oliveira RJT, Oliveira CMS, Meirelles BHS, Mello ALSF, Magalhaes ALP. O pensamento complexo e suas repercussões na gestão em enfermagem e saúde. Aquichan. 2016;16(4):501-12. doi: 10.5294/aqui.2016.16.4.8

9. Morin E. Introdução ao pensamento complexo / Edgar Morin; tradução Eliane Lisboa. 5.ed., Porto Alegre: Sulina; 2015.

10. Backes DS, Zamberlan C, Siqueira HCHD, Backes MTS, Sousa FGMD, Lomba MDLLDF. Quality nursing education: a complex and multidimensional phenomenon. Texto Contexto Enferm. 2018;27(3):e4580016. doi: 10.1590/0104-070720180004580016

11. Backes DS, Zamberlan C, Colomé J, Souza MT, Marchiori MT, Erdmann AL, et al. Systemic interactivity between Interdependent concepts of nursing care. Aquichan. 2016;16(1):24-31. doi: 10.5294/aqui.2016.16.1.4

12. Heidegger M. Ser e Tempo. Petrópolis: Vozes; 2009. 